\title{
Effect of Vitamin C, Red Pepper and Oak Leaves on Physiological and Productive Performance of Quail*
}

\author{
Ihsan T. TAYEB ${ }^{1 * *}$, Saeb Younis ABDUL-RAHMAN ${ }^{2}$, Narin Nidhamalddin SIDEEQ $^{1}$ \\ ${ }^{1}$ Dohuk Polytechnic University, Amedi Technical Institute, Department of Animal Resources. Iraq \\ ${ }^{2}$ University of Mosul, College of Agriculture and Forestry, Department of Animal Resources, Iraq \\ ${ }^{3}$ Ministry of Education, Iraq
}

\author{
Received (Geliş): 16.07.2014
}

Accepted (Kabul): 13.04.2015

\begin{abstract}
The current study was conducted on the animal production college of agriculture and forestryUniversity of Duhok, in order to investigate the effect of ration supplementation with vitamin C, red pepper (RP) and oak leaves (OL) on some physiological, reproductive and productive parameters of quail. Four hundred eighty quail birds ( 7 days) were divided into four groups with three replicates / group (40 birds/replicate, the groups were treated from the age of 7 days till the age of 49 days as follows: T1 (control): Reread on standard ration, T2: Reread on standard ration supplemented with vitamin $\mathrm{C}(300 \mathrm{mg} / \mathrm{kg}$ ration). T3: Reread on standard ration supplemented with red pepper crush (5g/kg ration). T4: Reread on standard ration supplemented with oak leaves crush $(10 \mathrm{~g} / \mathrm{kg}$ ration).The results of the current study revealed the following: Significant increase in live body weight (LBW) and body weight gain (BWG) of treatment as compared with control, significant decrease in feed consumption (FC) in vit. C group as compared with control, a significant improvement feed conversion ratio (FCR) in OL group as compared with control and in RP and vit. C groups as compared with OL group, a significant decrease in carcass weight of RP group as compared with control and OL groups and in heart relative weight as compared with vit. C group. Significant increase in mean egg weight, hen day (HD) \% and egg mass/hen in OL group as compared with control and in as compared with other treatments. Significant increase in serum total protein (TP) and globulin in OL group as compared with vit. C group and a significant decrease in serum albumin in RP group as compared with control of male quail and a significant decrease in serum TP, globulin, albumin and TG in all groups as compared with control of female quail, a significant decrease in Cholesterol in OL group compared with control and in glucose as compared with RP and vit. C groups. Significant improvement in Lymphocyt (L)\%, Heterophil (H)\% and stress index in OL group of female quail and in $\mathrm{L} \%$ and in $\mathrm{H} \%$ in vit. $\mathrm{C}$ group of male quail significant improvement in yolk index in OL group and in shell membrane thickness in control group.
\end{abstract}

Key words: Oak leaves, Quail, Production, Red pepper and Vitamin C

\section{INTRODUCTION}

Recently there has been an increased demand on white meat and eggs protein due to their nutritional value and health benefits as compared with red meat, and it is considered an important source of nutrition for human beings. It is well known that poultry nutrition is one of the most important factor that affect growth, immunity and quality of chick offspring (Kidd et al 2003). In poultry industry, the intensive programs of production lead to great stresses on birds, and cause a negative impact on growth, and immunity due to the alterations in physiological and hormonal performance (Donker et al. 1990). Poultry production is also subjected to many problems such as the high initial cost of chick, high nutritional cost, management, the use of vaccine and antibiotics. As a solution to these problems a new products (species) as the quail was introduced in poultry industry. The quail is characterized by being a dual purpose bird and highly resistant to diseases and environmental condition without the use of vaccines, as well as, the high nutritional value of quail meat and eggs that was used to solve some of the above problems.
Vitamin C (L-ascorbic acid, AA) has an important metabolic role as a result of its reducing properties and functions as an electron carrier (Whitehead and Keller, 2003). AA can be synthesized by poultry (Lin et al. 2006) but the endogenous source of AA may not be adequate to meet the full needs of poultry at all times and/or the requirement for AA maybe increased under stressful conditions, like rapid growth and intensive egg production (Whitehead and Keller, 2003; AbdulRahman and Alrahawi, 2012). Medicinal plants and herbs has taken great attention for their antioxidant capacity, and are used in poultry industry to improve the physiological, productive and reproductive performance (Barreto et al. 2008; Taha and Abdul- Rahman, 2011; Al-krad et al. 2012; Abdul-Rahman and Alobaidy, 2013 and Abdul- Rahman and Al-Kattan, 2013;).

Red pepper, a plant belongs to the family (solanaceae) enhances immunity in rats (Akimoto et al. 2009), reduces blood sugar in dogs (Tolan et al. 2001) and in broiler (Ibrahim and Potros, 2009), It also improves the antioxidant status in rabbits (Alishlash, 2012).

\footnotetext{
*Article part of M.sc thesis

**Corresponding author: Tayeb, I.T., ihsan.tayeb@hotmail.com
} 
Oak tree species are rich in phenolic compounds as galic acid and ellagic acid (Fernandez et al. 1996). Few studies are concerned with the physiological effects of oak leaves, Abdul- Rahman et al. (2001) evaluated the hypoglycemic and hypocholesterolemic effect of oak leaves boiled extract in chicken, and Abdul- Rahman et al. (2005); and Abdul- Rahman, (2008) studied the oak leaves boiled extract effect in rabbits.

The current study aim is to evaluate the effect of Vitamin C, Red pepper and oak leaves on some physiological, productive and reproductive performance aspects of quails.

\section{MATERIALS and METHODS}

The study was conducted in the Animal Production department, Faculty of Agriculture, University of Duhok, to investigate the effect of ration supplementation with Vitamin C, Red pepper and Oak leaves on some physiological reproductive and productive performance aspects of quails. A total of 800 fertile eggs were placed in the incubators machines. At the age of (7days), 480 birds were divided randomly into four groups (120 birds/group). With three replicates/group (40 birds/ replicate). The four groups were treated as follows from the age of 7days till the age of 49 days (for 6 weeks): T1: Birds were reared on the standard ration (control group). T2: Birds were reared on the standard ration supplemented with vitamin $\mathrm{C}$ (300 $\mathrm{mg} / \mathrm{kg}$ ration). T3: Birds were reared on the standard ration supplemented with red pepper crush (5 $\mathrm{g} / \mathrm{kg}$ ration). T4: Birds were reared on the standard ration supplemented with oak leaves crush $(10 \mathrm{gm} / \mathrm{kg}$ ration). The feed was supplied manually through the experimental period, the birds were fed two rations, starter ration (1-21days) and grower and productive ration ( 22 days- end of experiment). The two rations that used for birds feeding were explained in table (1).

Throw the experiments this parameter was measured live body weight, weekly weight gain, feed intake, feed conversion ratio and egg production. At the age of 49 days birds were slaughtered, blood were collected, dressing percentage, $\mathrm{H} / \mathrm{L}$ ratio, total protein, serum albumin, globulin, serum glucose, triglyceride, cholesterol. The experiment was designed by C.R.D and the collected data were analyzed by one-way analysis of variance using SAS (SAS, 2008). Then Duncan multiple range test (Duncan 1955) was used to determine the differences between means.

\section{RESULTS and DISCUSSIONS}

Table 2 reveals the effect of vitamin $\mathrm{C}$, red pepper, oak leaves on body weight of quail, in the $(1,2,3)$ weeks of treatment and there was a significant increase in body weight compared to control group. Table 3 shows that oak leaves treatment causes a significant increase on weight gain at the first week as compared with control, red pepper treatment causes a significant increase in weight gain at the third week of treatment as compared with control at ( $\mathrm{p} \unlhd 0.05$ ).

Table 4 reveals a significant increase in feed consumption on the first and second weeks of treatment in oak leaves group and control group as compared with vitamin $\mathrm{C}$, a significant increase in oak leaves group on the third week of treatment as compared with control group at ( $\mathrm{p} \unlhd 0.05$ ).

Table 1. Chemical analysis of quail rations during the experimental

\begin{tabular}{lcc} 
& \multicolumn{2}{c}{ Rations } \\
\cline { 2 - 3 } Ingredient\% & Starter & Growth and production \\
\hline Yellow corn & 36 & 42 \\
Wheat & 22 & 22 \\
Soybean meal (44\%) & 35 & 30 \\
Protein concentration & 5 & 4 \\
Sunflower oil & 1 & 1 \\
Limestone ( Ca+2) & 0.7 & 0.7 \\
Salt & 0.3 & 0.3 \\
Total & 100 & 100 \\
\hline Chemical composition \% (calculated) as feed & & 21.590 \\
Crude protein & 23.670 & 2895.600 \\
ME(cal/kg) & 2861.800 & 89.980 \\
Dry matter & 90.410 & 3.310 \\
Ether extract & 3.140 & 3.780 \\
Crude fiber & 4.050 & 1.210 \\
Lysine & 1.378 & 0.515 \\
Methionine & 0.572 & 0.786 \\
Meth. + Cys. & 0.871 & 0.456 \\
Calcium & 0.507 & 0.214 \\
Phosphorous & 0.274 & \\
\hline - Protin & & \\
\hline
\end{tabular}

*: Protein concentrates 40\%: Table 3.

**: Calculated from NRC. 1994. (Appendix 2) 
Table 5 shows a significant decrease (improvement) in F.C.R. on the first week of treatment in oak leaves group was observed as compared with control, in vitamin $\mathrm{C}$ and red pepper groups on the second week of treatment as compared with oak leaves group at ( $\mathrm{p} \leq$ $0.05)$.

The results of vitamin $\mathrm{C}$ on live body weight (LBW) and FCR were in agreement with the finding of Usman et al., (2008); Abdul-Rahman and Al-Rahawi 2012); Tuleun et al. (2011); Al-krad et al. 2012 and AbdulMajeed, (2013) in quails. Whereas the results in WG were in agreement with Abdul-Rahman and Al-Rahawi 2012; Al-krad et al. (2012) and Abdul-Majeed, (2013) in quail.

The results on FC were in agreement with the findings of Al-Rahawi, 2010 in quail, with those of Puthpongsiriporn et al. (2001) and Mbajiorgu, (2011) in laying hens and also with the finding of Konca et al. (2009); Tayeb et al. (2011) and Al-krad et al., (2012) in broiler. The effects of vitamin $\mathrm{C}$ may be due to the positive effect of vitamin $\mathrm{C}$ as antioxidant that enhanced the thyroid function (El-Fiky, 1998) and the protection of intestinal mucosal lining and the improvement of digestive function in feed assimilation (Abdul-Majeed, 2013). On the other hand, the effect of red pepper on LBW, FC and were generally in agreement with the finding of (Barreto et al. 2008) who stated that the addition of red pepper to broiler diet did not affect LBW and $\mathrm{FC}$, also the results of the current study in LBW specially in the second and third weeks of treatment were in agreement with (Alkassie et al. 2011) who reported a significant increase in WG of broiler when red pepper was added to the diet, while the results in FC and FCR were in disagreement with (Alkassie et al. 2011) finding who stated an improvement in FC and FCR when red pepper was added to broiler diet. The absence of obvious effects of red pepper on LBW, WG and FCR may be due to the active ingredient Capsaicin which increased energy utilization and fat metabolism (Smeets and Lejeune, 2005), Capsaicin enhances energy metabolisms and utilization through catecholamine secretion from adrenal medulla as a result of central nervous system activation which mediated through thermo- sensitive transient receptor potential (TRP) type V1 (Kobata et al. 2006).

Table 2. The effect of Vitamin C, Red pepper and Oak leaves on body weight (gm) of quail

\begin{tabular}{|c|c|c|c|c|c|c|}
\hline \multirow[b]{2}{*}{ Treatments } & \multirow{2}{*}{$\begin{array}{l}\text { Initial body } \\
\text { weight } \\
\text { (7days) }\end{array}$} & \multicolumn{5}{|c|}{ Weeks of treatment } \\
\hline & & $\begin{array}{l}1^{\mathrm{st}} \\
(14 \text { days })\end{array}$ & $2^{\text {nd }}$ & $3^{\text {rd }}$ & $4^{\text {th }}$ & $5^{\text {th }}$ \\
\hline Control & $37.09 \pm 0.45^{\mathrm{a}}$ & $74.83 \pm 3.36^{\mathrm{b}}$ & $126.46 \pm 0.89^{b}$ & $167.33 \pm 0.46^{\mathrm{c}}$ & $209.41 \pm 1.58^{\mathrm{a}}$ & $226.28 \pm 1.53^{\mathrm{a}}$ \\
\hline $\begin{array}{l}\text { Vit. C } 300 \text { mg } \\
\text { /Kg ration }\end{array}$ & $37.93 \pm 0.88^{\mathrm{a}}$ & $81.00 \pm 1.59^{\mathrm{ab}}$ & $129.87 \pm 2.05^{\mathrm{ab}}$ & $172.75 \pm 1.60^{\mathrm{ab}}$ & $213.62 \pm 3.56^{\mathrm{a}}$ & $228.62 \pm 3.38^{\mathrm{a}}$ \\
\hline $\begin{array}{l}\text { Red pepper } \\
5 \mathrm{~g} / \mathrm{Kg} \text { ration }\end{array}$ & $38.22 \pm 0.12^{\mathrm{a}}$ & $81.54 \pm 0.30^{\mathrm{ab}}$ & $131.67 \pm 0.79^{\mathrm{a}}$ & $175.08 \pm 0.60^{\mathrm{a}}$ & $213.00 \pm 2.04^{\mathrm{a}}$ & $232.54 \pm 0.47^{\mathrm{a}}$ \\
\hline $\begin{array}{l}\text { Oak leaves } 10 \\
\mathrm{gm} / \mathrm{kg} \text { ration }\end{array}$ & $37.32 \pm 0.43^{\mathrm{a}}$ & $85.71 \pm 2.83^{\mathrm{a}}$ & $129.62 \pm 1.48^{\mathrm{b}}$ & $171.33 \pm 0.84^{\mathrm{b}}$ & $213.33 \pm 1.62^{\mathrm{a}}$ & $226.28 \pm 2.55^{\mathrm{a}}$ \\
\hline
\end{tabular}

Values represent: means $\pm \mathrm{SE}$.

Different letters in each column mean significant differences at (P $₫ 0.05$ ).

Table 3. The effect of vitamin c, red pepper and oak leaves on weight gain (gm/ bird / week) of quail

\begin{tabular}{|c|c|c|c|c|c|c|}
\hline \multirow[b]{2}{*}{ Treatments } & \multicolumn{5}{|c|}{ Weeks of treatment } & \multirow{2}{*}{$\begin{array}{l}\text { accumulative } \\
\text { weight gain }\end{array}$} \\
\hline & $1^{\text {st }}(14 \mathrm{~d})$ & $2^{\text {nd }}$ & $3^{\text {rd }}$ & $4^{\text {th }}$ & $5^{\text {th }}$ & \\
\hline Control & $37.74 \pm 3.60^{\mathrm{b}}$ & $51.62 \pm 2.90^{\mathrm{a}}$ & $40.87 \pm 0.43^{b}$ & $42.08 \pm 1.16^{\mathrm{a}}$ & $16.86 \pm 0.76^{\mathrm{a}}$ & $189.19 \pm 1.51^{\mathrm{a}}$ \\
\hline $\begin{array}{l}\text { Vit. C } 300 \mathrm{mg} / \mathrm{Kg} \\
\text { ration }\end{array}$ & $43.06 \pm 0.71^{\mathrm{ab}}$ & $48.87 \pm 2.03^{\mathrm{a}}$ & $42.87 \pm 0.56^{\mathrm{ab}}$ & $40.87 \pm 2.34^{\mathrm{a}}$ & $15.00 \pm 0.18^{\mathrm{a}}$ & $190.69 \pm 2.57^{\mathrm{a}}$ \\
\hline $\begin{array}{l}\text { Red pepper } \\
5 \mathrm{gm} / \mathrm{Kg} \text { ration }\end{array}$ & $43.32 \pm 0.42^{\mathrm{ab}}$ & $50.12 \pm 0.92^{\mathrm{a}}$ & $43.42 \pm 0.25^{\mathrm{a}}$ & $37.91 \pm 1.44^{\mathrm{a}}$ & $19.54 \pm 2.49^{\mathrm{a}}$ & $194.32 \pm 0.55^{\mathrm{a}}$ \\
\hline $\begin{array}{l}\text { Oak leaves } \\
10 \mathrm{gm} / \mathrm{kg} \text { ration }\end{array}$ & $48.39 \pm 2.89^{\mathrm{a}}$ & $43.91 \pm 4.23^{\mathrm{a}}$ & $41.71 \pm 1.10^{\mathrm{ab}}$ & $42.00 \pm 2.31^{\mathrm{a}}$ & $13.35 \pm 3.78^{\mathrm{a}}$ & $189.37 \pm 2.98^{\mathrm{a}}$ \\
\hline
\end{tabular}

Values represent: means $\pm \mathrm{SE}$.

Different letters in each column mean significant differences at (P $₫ 0.05$ ). 
Table 4. The effect of vitamin C, red pepper and oak leaves on feed consumption (gm/week/bird) of quail

\begin{tabular}{|c|c|c|c|c|c|c|}
\hline \multirow{2}{*}{ Treatments } & \multicolumn{6}{|c|}{ Weeks of treatment } \\
\hline & $1^{\text {st }}(14 \mathrm{~d})$ & $2^{\text {nd }}$ & $3^{\text {rd }}$ & $4^{\text {th }}$ & $5^{\text {th }}$ & $6 \mathrm{t}^{\mathrm{h}}$ \\
\hline Control & $\underset{\mathrm{a}}{120.08 \pm 1.80}$ & $\underset{\mathrm{a}}{150.03 \pm 5.96}$ & $\underset{b}{148.00 \pm 1.37}$ & $181.37 \pm 4.40$ & $\begin{array}{l}180.17 \pm 16.4 \\
5^{\mathrm{a}}\end{array}$ & $181.83 \pm 4.57^{\mathrm{a}}$ \\
\hline $\begin{array}{l}\text { Vit.C300 } \\
\text { mg/Kg ration }\end{array}$ & ${ }_{b}^{111.04 \pm 2.56}$ & $\underset{b}{120.04 \pm 4.62}$ & $\underset{\mathrm{ab}}{152.33 \pm 1.37}$ & $175.54 \pm 4.75$ & $\underset{\mathrm{a}}{189.22 \pm 9.65}$ & $181.71 \pm 13.39^{\mathrm{a}}$ \\
\hline $\begin{array}{l}\text { Red pepper } \\
5 \mathrm{gm} / \mathrm{Kg} \text { ration }\end{array}$ & $\underset{\mathrm{ab}}{116.88 \pm 1.90}$ & $\begin{array}{l}128.58 \pm 10.0 \\
3^{\mathrm{ab}}\end{array}$ & $\underset{\mathrm{ab}}{154.00 \pm 2.59}$ & $\underset{\mathrm{a}}{184.96 \pm 4.80}$ & $\underset{\mathrm{a}}{181.08 \pm 4.45}$ & $190.50 \pm 4.45^{\mathrm{a}}$ \\
\hline $\begin{array}{l}\text { Oak leaves } 10 \\
\mathrm{gm} / \mathrm{kg} \text { ration }\end{array}$ & $\underset{\mathrm{a}}{120.96 \pm 1.77}$ & $\underset{\mathrm{a}}{145.37 \pm 4.19}$ & $\underset{\mathrm{a}}{155.25 \pm 2.09}$ & $\underset{\mathrm{a}}{183.71 \pm 3.33}$ & $\underset{\mathrm{a}}{174.18 \pm 3.34}$ & $187.50 \pm 5.62^{\mathrm{a}}$ \\
\hline
\end{tabular}

Values represent: means \pm SE.

Different letters in each column mean significant differences at (P $₫ 0.05$ ).

In the current study, the supplementation of oak leaves crush in a level of $1 \%$ with the quail diet did not exhibit any passive effects on LBW,WG, FC and FCR, This may reflect the palatability of oak leaves and that the birds accepted the flavor and taste of the leaves and did not refuse the diet so that the growth parameters were in normal ranges, The oak leaves were used previously for goat, sheep and cattle nutrition without any adverse effects (Paterson, 1993) and Lupton et al. (1996) too stated that rearing goats on the oak leaves enhance WG.

Table 5. The effect of vitamin C, red pepper and oak leaves on feed conversion ratio of quail

\begin{tabular}{|c|c|c|c|c|}
\hline \multirow{2}{*}{ Treatments } & \multicolumn{4}{|l|}{ Weeks } \\
\hline & $1^{\mathrm{st}}(14 \mathrm{~d})$ & $2^{\text {nd }}$ & $3^{\text {rd }}$ & $4^{\text {th }}$ \\
\hline Control & $3.25 \pm 0.39^{\mathrm{a}}$ & $2.93 \pm 0.23^{\mathrm{ab}}$ & $3.62 \pm 0.05^{\mathrm{a}}$ & $4.32 \pm 0.19^{\mathrm{a}}$ \\
\hline $\begin{array}{l}\text { Vit. C } 300 \\
\mathrm{mg} / \mathrm{Kg} \text { ration }\end{array}$ & $2.57 \pm 0.03^{\mathrm{ab}}$ & $2.46 \pm 0.10^{\mathrm{b}}$ & $3.55 \pm 0.07^{\mathrm{a}}$ & $4.31 \pm 0.16^{\mathrm{a}}$ \\
\hline $\begin{array}{l}\text { Red pepper } \\
5 \mathrm{gm} / \mathrm{Kg} \text { ration }\end{array}$ & $2.70 \pm 0.07^{\mathrm{ab}}$ & $2.56 \pm 0.15^{\mathrm{b}}$ & $3.55 \pm 0.07^{\mathrm{a}}$ & $4.88 \pm 0.06^{\mathrm{a}}$ \\
\hline $\begin{array}{l}\text { Oak leaves } \\
10 \mathrm{gm} / \mathrm{kg} \text { ration }\end{array}$ & $2.51 \pm 0.11^{\mathrm{b}}$ & $3.36 \pm 0.27^{\mathrm{a}}$ & $3.73 \pm 0.13^{\mathrm{a}}$ & $4.41 \pm 0.33^{\mathrm{a}}$ \\
\hline
\end{tabular}

Values represent: means \pm SE.

Different letters in each column mean significant differences at (P $₫ 0.05$ ).

Table 6 represents the effect of treatment on egg production parameters for the period (42days age to 49 days age). The results also showed a significant increase in egg number/week in red pepper treatment group as compared with oak leaves and vitamin $\mathrm{C}$ treatments and a significant increase in mean egg weight was recorded in oak leaves group as compared with control group at (p 50.05 ). The result revealed a significant increase in $\mathrm{HD} \%$ and egg mass in oak leaves group as compared with red pepper group, vitamin $\mathrm{C}$ group and control group, The $\mathrm{HD} \%$ and egg mass value in vitamin $\mathrm{C}$ group were significantly better than that of control

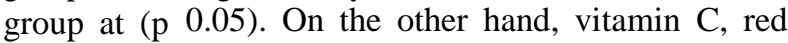
pepper and oak leaves treatments improved the F.C.R. and the values of F.C.R. in oak leaves group were significantly improved as compared with control group at $(\mathrm{p} \$ 0.05)$. The results were in agreement with the finding of (Hemid et al. 2010 and Abdul-Majeed, 2013) home reported the positive effect of vitamin $\mathrm{C}$ on $\mathrm{HD} \%$ and egg mass may be due to the inhibitory effect of vitamin $\mathrm{C}$ on the stress hormone (corticosterone), the addition of vitamin $\mathrm{C}$ to quail diet caused a significant decrease in corticosterone level. There was a negative correlation between corticosterone and the gonadotropins (LH and FSH), so the gonadotropin would enhance ovary growth and function (Erhan and Bölükbaşi, 2011). In regard to the oak leaves effects that improved significantly the egg weight, $\mathrm{HD} \%$, egg mass and FCR Table 8. This may reflect the palatability of oak leaves and their enhancement of the digestive system function in feed assimilation, also the role of oak leaves constituents as the polyphenols gallic and ellagic acids that possessed antioxidant activities (Zoi Papoutsi et al. 2005). 
Table 6. The effect of Vitamin C, Red pepper and Oak leaves on egg production parameters of quail

\begin{tabular}{|c|c|c|c|c|c|c|c|}
\hline \multirow[b]{2}{*}{ Treatments } & \multicolumn{6}{|c|}{ Age 42 days - 49 days } & \multirow[b]{2}{*}{ FCR } \\
\hline & $\begin{array}{c}\text { Egg } \\
\text { number/week }\end{array}$ & $\begin{array}{l}\text { Egg weight/ } \\
\text { week(gm) }\end{array}$ & $\begin{array}{c}\text { Mean egg } \\
\text { weight } \\
\text { (gm) }\end{array}$ & $\mathrm{HD} \%$ & $\begin{array}{l}\text { Egg mass gm } \\
\text { /hen/ day }\end{array}$ & $\mathrm{FC}(\mathrm{gm})$ & \\
\hline Control & $85.00 \pm 2.51 \mathrm{ab}$ & $898.93 \pm 37.59 a$ & $10.57 \pm 0.18 b$ & $58.72 \pm 0.81 \mathrm{c}$ & $6.20 \pm 0.18 \mathrm{c}$ & $3460.75 \pm 151.58 \mathrm{a}$ & $3.90 \pm 0.07 a$ \\
\hline $\begin{array}{l}\text { Vit. C } 300 \mathrm{mg} / \\
\text { Kg ration }\end{array}$ & $81.33 \pm 2.02 b$ & $885.06 \pm 33.51 \mathrm{a}$ & $10.87 \pm 0.18 a b$ & $62.23 \pm 0.88 b$ & $6.76 \pm 0.21 b$ & $3154.50 \pm 280.45 \mathrm{a}$ & $3.56 \pm 0.31 \mathrm{ab}$ \\
\hline $\begin{array}{l}\text { Red pepper } \\
\text { gm } / \mathrm{kg} \text { ration }\end{array}$ & $88.66 \pm 1.76 \mathrm{a}$ & $968.78 \pm 21.59 \mathrm{a}$ & $10.92 \pm 0.04 \mathrm{ab}$ & $61.29 \pm 0.79 \mathrm{cb}$ & $6.69 \pm 0.08 \mathrm{cb}$ & $3538.67 \pm 65.00 \mathrm{a}$ & $3.65 \pm 0.05 \mathrm{ab}$ \\
\hline $\begin{array}{l}\text { Oak leaves } 10 \\
\mathrm{gm} / \mathrm{kg} \text { ration }\end{array}$ & $80.33 \pm 0.88 b$ & $900.36 \pm 6.49 \mathrm{a}$ & $11.21 \pm 0.12 \mathrm{a}$ & $64.98 \pm 0.83 a$ & $7.27 \pm 0.10 \mathrm{a}$ & $2943.50 \pm 109.68 \mathrm{a}$ & $3.26 \pm 0.10 \mathrm{~b}$ \\
\hline
\end{tabular}

Values represent: means \pm SE.

Different letters in each column mean significant differences at (P $₫ 0.05$ ).

Table 7 revealed a significant increase at (p $₫ 0.05)$ in carcass weight in oak leaves group as compared with red pepper which was significantly decreased as compared with control group and significant increase in heart \%in vitamin $\mathrm{C}$ group as compared with red pepper group at ( $\mathrm{p} \unlhd 0.05)$. The results of Vit. $\mathrm{C}$ on carcass and internal organs were in agreement with those of (AbdulRahman and Al-Rahawi 2012; Abdul-Majeed, 2013) may due to the stress of growth and rapid productivity of quail (egg laying) by the reaction of vit. $\mathrm{C}$ with the reactive oxygen species, mainly the superoxide anion radical, hydroxyl radical and hydrogen peroxide, forming semidehydroascorbic acid and this will protect tissues from oxidative damage (Tayeb et al., 2011).

Table 8 and 9 shows a significant increase in lymphocyte \% of male quail in vitamin $\mathrm{C}$ group as compared with control, red pepper and oak leaves treatment and of female quail in oak leaves group as compared with vitamin $\mathrm{C}$ group at ( $\mathrm{s} \unlhd .05$ ). There was also a significant decrease in heterophil \% of male in vitamin $\mathrm{C}$ group as compared with control, red pepper and of female quail in oak leaves group as compared with control and vitamin $C$. On the other hand, monocyte $\%$ of female quail was significantly increased in red pepper group as compared with control group at ( $\mathrm{p} \ 0.05$ ). In regard the stress index oak leaves treatment caused a significant decrease in female quail as compared with control and vitamin $\mathrm{C}$. The result of vitamin $\mathrm{C}$ on differential leucocytes counts (DLC) was in agreement with (Al-krad et al. 2012) and (AbdulMajeed, 2013), specially for the Lymphocytes \% and Heterophil $\%$ and a disagreement with the two above mentioned researchers in $\mathrm{H} / \mathrm{L}$ ratio. The results of red pepper were in agreement with the finding of (Akimoto et al. 2009 and Alkassie et al. 2011) in rat especially in basophils $\%$ and eosinophils $\%$ and monocytes $\%$.

Table 7. The effect of Vitamin C, Red pepper and Oak leaves on some carcass parameters of female quail

\begin{tabular}{lccccccc}
\hline \multicolumn{1}{c}{ Treatments } & $\begin{array}{c}\text { Live body } \\
\text { weight }(\mathrm{gm})\end{array}$ & $\begin{array}{c}\text { Carcass } \\
\text { weight }(\mathrm{gm})\end{array}$ & Dressing $\%$ & Liver\% & Heart\% & Pancreas \% & Gizzard \% \\
\hline Control & $264.33 \pm 8.13 \mathrm{a}$ & $\begin{array}{l}196.68 \pm 0.56 \\
\mathrm{a}\end{array}$ & $74.72 \pm 2.07 \mathrm{a}$ & $2.89 \pm 0.36 \mathrm{a}$ & $0.72 \pm 0.02 \mathrm{ab}$ & $0.19 \pm 0.01 \mathrm{a}$ & $1.79 \pm 0.12 \mathrm{a}$ \\
\hline $\begin{array}{l}\text { Vit. C } 300 \mathrm{mg} / \mathrm{Kg} \\
\text { ration }\end{array}$ & $259.33 \pm 3.39 \mathrm{a}$ & $\begin{array}{l}192.24 \pm 2.22 \\
\mathrm{ab}\end{array}$ & $74.09 \pm 0.55 \mathrm{a}$ & $2.53 \pm 0.16 \mathrm{a}$ & $0.82 \pm 0.05 \mathrm{a}$ & $0.19 \pm 0.01 \mathrm{a}$ & $1.75 \pm 0.16 \mathrm{a}$ \\
\hline $\begin{array}{l}\text { Red pepper } \\
\text { 5gm/Kg ration }\end{array}$ & $250.00 \pm 5.11 \mathrm{a}$ & $\begin{array}{l}183.30 \pm 3.83 \\
\mathrm{~b}\end{array}$ & $73.32 \pm 0.03 \mathrm{a}$ & $2.94 \pm 0.33 \mathrm{a}$ & $0.69 \pm 0.03 \mathrm{~b}$ & $0.19 \pm 0.02 \mathrm{a}$ & $1.73 \pm 0.07 \mathrm{a}$ \\
\hline $\begin{array}{l}\text { Oak leaves 10 } \\
\text { gm/kg ration }\end{array}$ & $270.66 \pm 11.7 \mathrm{a}$ & $\begin{array}{l}200.69 \pm 6.70 \\
\mathrm{a}\end{array}$ & $74.32 \pm 0.86 \mathrm{a}$ & $2.35 \pm 0.04 \mathrm{a}$ & $0.80 \pm 0.02 \mathrm{ab}$ & $0.23 \pm 0.02 \mathrm{a}$ & $1.77 \pm 0.11 \mathrm{a}$ \\
\hline
\end{tabular}

Values represent: means \pm SE.

Different letters in each column means significant differences at (P $₫ 0.05)$.

Table 8. The effect of Vitamin C, red pepper and oak leaves on differential leucocyte counts of male quail

\begin{tabular}{lllllll}
\hline Treatments & Lymphocyt \% & Heterophil \% & Monocyte \% & Eosinophil \% & Basophil \% & Stress index \% \\
\hline Control & $72.00 \pm 2.11 \mathrm{~b}$ & $26.16 \pm 1.77 \mathrm{a}$ & $1.33 \pm 0.44 \mathrm{a}$ & $0.66 \pm 0.33 \mathrm{a}$ & $0.00 \pm 0.00 \mathrm{a}$ & $0.36 \pm 0.03 \mathrm{a}$ \\
\hline $\begin{array}{l}\text { Vit. C } \\
300 \mathrm{mg} / \mathrm{Kg} \text { ration }\end{array}$ & $77.83 \pm 2.24 \mathrm{a}$ & $20.16 \pm 1.68 \mathrm{~b}$ & $1.16 \pm 0.47 \mathrm{a}$ & $0.83 \pm 0.40 \mathrm{a}$ & $0.00 \pm 0.00 \mathrm{a}$ & $0.26 \pm 0.02 \mathrm{a}$ \\
\hline $\begin{array}{l}\text { Red pepper } \\
5 \mathrm{gm} / \mathrm{Kg} \text { ration }\end{array}$ & $72.16 \pm 1.88 \mathrm{~b}$ & $25.16 \pm 1.51 \mathrm{a}$ & $1.50 \pm 0.50 \mathrm{a}$ & $1.16 \pm 0.47 \mathrm{a}$ & $0.00 \pm 0.00 \mathrm{a}$ & $0.35 \pm 0.02 \mathrm{a}$ \\
\hline $\begin{array}{l}\text { Oak leaves } \\
10 \mathrm{gm} / \mathrm{kg} \text { ration }\end{array}$ & $71.50 \pm 0.95 \mathrm{~b}$ & $26.00 \pm 0.46 \mathrm{a}$ & $1.66 \pm 0.42 \mathrm{a}$ & $0.83 \pm 0.30 \mathrm{a}$ & $0.00 \pm 0.00 \mathrm{a}$ & $0.36 \pm 0.01 \mathrm{a}$ \\
\hline
\end{tabular}

Values represent: means \pm SE.

Different letters in each column means significant differences at ( $\mathrm{P} \unlhd 0.05$ ). 
Table 9. The effect of Vitamin C, Red pepper and Oak leaves on differential leucocyte counts of female quail

\begin{tabular}{|c|c|c|c|c|c|c|}
\hline Treatments & $\begin{array}{c}\text { Lymphocyt } \\
\%\end{array}$ & Heterophil \% & $\begin{array}{c}\text { Monocyte } \\
\%\end{array}$ & $\begin{array}{c}\text { Eosinophil } \\
\%\end{array}$ & $\begin{array}{c}\text { Basophil } \\
\%\end{array}$ & $\begin{array}{l}\text { Stress index } \\
\%\end{array}$ \\
\hline Control & $72.50 \pm 1.89 \mathrm{ab}$ & $26.50 \pm 1.66 \mathrm{a}$ & $0.83 \pm 0.16 b$ & $0.33 \pm 0.33 b$ & $0.00 \pm 0.00 \mathrm{a}$ & $0.37 \pm 0.03 a$ \\
\hline $\begin{array}{l}\text { Vit. C } 300 \mathrm{mg} / \mathrm{Kg} \\
\text { ration }\end{array}$ & $70.33 \pm 1.08 b$ & $26.50 \pm 0.88 \mathrm{a}$ & $1.66 \pm 0.33 \mathrm{ab}$ & $1.50 \pm 0.22 \mathrm{a}$ & $0.00 \pm 0.00 \mathrm{a}$ & $0.37 \pm 0.01 \mathrm{a}$ \\
\hline $\begin{array}{l}\text { Red pepper5 } \mathrm{gm} / \mathrm{Kg} \\
\text { ration }\end{array}$ & $74.33 \pm 1.62 \mathrm{ab}$ & $22.50 \pm 1.92 \mathrm{ab}$ & $1.83 \pm 0.30 \mathrm{a}$ & $1.33 \pm 0.21 \mathrm{a}$ & $0.00 \pm 0.00 \mathrm{a}$ & $0.30 \pm 0.03 \mathrm{ab}$ \\
\hline $\begin{array}{l}\text { Oak leaves } 10 \mathrm{gm} / \mathrm{kg} \\
\text { ration }\end{array}$ & $75.33 \pm 1.22 \mathrm{a}$ & $21.50 \pm 1.25 b$ & $1.66 \pm 0.33 \mathrm{ab}$ & $1.66 \pm 0.30 \mathrm{a}$ & $0.00 \pm 0.00 \mathrm{a}$ & $0.28 \pm 0.02 b$ \\
\hline
\end{tabular}

Values represent: means \pm SE.

Different letters in each column mean significant differences at ( $\mathrm{P} \unlhd 0.05)$.

Table 10 explain the effect of vit.C, red pepper and oak leaves on blood serum of male quail, the table showed a significant increase $(\mathrm{p} \unlhd(05)$ in serum total protein and globulin, in oak leaves as compared with vitamin $\mathrm{C}$ and a significant decrease ( $\mathrm{p} \unlhd 0.05$ ), in albumin in red pepper group as compared with control group of male quail.

Table 11 explains the effect of vitamin $\mathrm{C}$, red pepper and oak leaves on blood serum of female quail. There was a significant decrease $(\mathrm{p} \unlhd 0.05)$ in total protein, in albumin and triglyceride in vitamin $\mathrm{C}$, red pepper and oak leaves treatment respectively as compared with control. There was also a significant decrease in Alb in red pepper group compared with oak leaves group., and there was a significant decrease in Glob in oak leaves group as compared with control and red pepper and a significant decrease $(\mathrm{p} \unlhd 0.05)$ in vitamin $\mathrm{C}$ compared with control. Treatment also causes a significant reduction ( $\mathrm{p} \unlhd 0.05$ ) in Chol. level, and in oak leaves group Chol. has been significantly decreased as compared with control. T.g has also been significantly decreased ( $\mathrm{p} \triangle 0.05$ ) in oak leaves as compared with vitamin $\mathrm{C}$ and red pepper and T.g in vitamin $C$ has been significantly decreased ( $p \unlhd 0.05$ ) as compared with red pepper group. On the other hand, Glu. is significantly increased ( $\mathrm{p} \unlhd 0.05$ ) in red pepper group as compared with oak leaves and control at ( $\mathrm{s} \unlhd .05$ ). The effects of vitamin $\mathrm{C}$ on triglyceride (TG) of female quail were in agreement with the finding of (Al-krad et al. 2012 and Abdul-Majeed, 2013), but they were in disagreement with (Abdul-Rahman and Alrahawi, 2012) in regard to the globulin and globulin: albumin ratio. The addition of vitamin $\mathrm{C}$ to the quail diet inhibited the stress hormone corticosterone (Abdul-Majeed, 2013). The results of red pepper on $\mathrm{TP}$ and Alb in female quail and on Alb in male quails were disagreement with the findings of (Trasel et al., 2010) in broiler and with (Abdel-Azim et al., 2009) in Mascovy ducks, These results may be due to the difference in the experimental animal (quail: egg laying) and in duration of the expriment.

Table 10. The effect of Vitamin C, Red pepper and Oak leaves on blood serum biochemical parameters of male quail.

\begin{tabular}{lllllll}
\hline Treatments & Tp gm/dl & Alb gm/dl & Glob gm/dl & Chol mg/dl & Tg mg/dl & Glu mg/dl \\
\hline Control & $2.97 \pm 0.18 \mathrm{ab}$ & $2.06 \pm 0.11 \mathrm{a}$ & $0.91 \pm 0.09 \mathrm{ab}$ & $156.40 \pm 13.34 \mathrm{a}$ & $215.40 \pm 15.01 \mathrm{a}$ & $345.52 \pm 10.76 \mathrm{a}$ \\
\hline $\begin{array}{l}\text { Vit. C } \\
\begin{array}{l}300 \mathrm{mg} / \mathrm{Kg} \\
\text { ration }\end{array}\end{array}$ & $2.53 \pm 0.13 \mathrm{~b}$ & $1.85 \pm 0.03 \mathrm{ab}$ & $0.68 \pm 0.10 \mathrm{~b}$ & $145.28 \pm 3.73 \mathrm{a}$ & $214.32 \pm 4.20 \mathrm{a}$ & $313.17 \pm 24.37 \mathrm{a}$ \\
\hline $\begin{array}{l}\text { Red pepper } \\
\begin{array}{l}\text { gm/Kg } \\
\text { ration }\end{array}\end{array}$ & $2.71 \pm 0.11 \mathrm{ab}$ & $1.76 \pm 0.08 \mathrm{~b}$ & $0.95 \pm 0.11 \mathrm{ab}$ & $155.95 \pm 7.90 \mathrm{a}$ & $199.22 \pm 2.89 \mathrm{a}$ & $329.94 \pm 9.21 \mathrm{a}$ \\
\hline $\begin{array}{l}\text { Oak leaves } 10 \\
\text { gm/kg ration }\end{array}$ & $3.10 \pm 0.15 \mathrm{a}$ & $1.84 \pm 0.10 \mathrm{ab}$ & $1.25 \pm 0.21 \mathrm{a}$ & $161.54 \pm 14.47 \mathrm{a}$ & $193.14 \pm 9.43 \mathrm{a}$ & $354.56 \pm 9.37 \mathrm{a}$ \\
\hline
\end{tabular}

Values represent: means \pm SE.

Different letters in each column means significant differences at (P $₫ 0.05)$.

*Tp: total protein, Alb: albumin, Glob: globulin, Chol: cholesterol, T.g: triglyceride, Glu: glucose 
Table 11. The effect of Vitamin C, Red pepper and Oak leaves on blood serum biochemical parameters of female quail

\begin{tabular}{lllllll}
\hline Treatments & Tp gm/dl & Alb gm/dl & Glob gm/dl & Chol mg/dl & T.g mg/dl & Glu mg/dl \\
\hline Control & $4.65 \pm 0.50 \mathrm{a}$ & $3.04 \pm 0.03 \mathrm{a}$ & $1.62 \pm 0.08 \mathrm{a}$ & $150.53 \pm 7.96 \mathrm{a}$ & $1236 \pm 37.06 \mathrm{a}$ & $287.79 \pm 17.66 \mathrm{bc}$ \\
\hline $\begin{array}{l}\text { Vit. C } \\
\text { 300mg/Kgration }\end{array}$ & $3.47 \pm 0.07 \mathrm{~b}$ & $2.30 \pm 0.11 \mathrm{bc}$ & $1.16 \pm 2.39 \mathrm{bc}$ & $132.18 \pm 2.39 \mathrm{ab}$ & $957.78 \pm 24.67 \mathrm{c}$ & $328.38 \pm 8.14 \mathrm{ab}$ \\
\hline $\begin{array}{l}\text { Red pepper } \\
\text { 5gm/Kg ration }\end{array}$ & $3.50 \pm 0.09 \mathrm{~b}$ & $2.16 \pm 0.04 \mathrm{c}$ & $1.34 \pm 0.08 \mathrm{ab}$ & $139.89 \pm 10.32 \mathrm{ab}$ & $1120.37 \pm 22.36 \mathrm{~b}$ & $345 \pm 15.76 \mathrm{a}$ \\
\hline $\begin{array}{l}\text { Oak leaves } \\
10 \text { gm/kg ration }\end{array}$ & $3.40 \pm 0.18 \mathrm{~b}$ & $2.53 \pm 0.17 \mathrm{~b}$ & $0.87 \pm 0.14 \mathrm{c}$ & $127.87 \pm 4.17 \mathrm{~b}$ & $816.81 \pm 58.38 \mathrm{~d}$ & $270.80 \pm 15.18 \mathrm{c}$ \\
\hline
\end{tabular}

Values represent: means \pm SE.

Different letters in each column means significant differences at (P $₫ 0.05$ ).

*Tp: total protein, Alb: albumin, Glob: globulin, Chol: cholesterol, T.g: triglyceride, Glu: glucose.

\section{CONCLUSION}

The absence of any passive effects on the nutritional parameters (LBW, FC and FCR) due to the ration supplementation with red pepper and oak leaves indicate the palatability and the acceptance of these plants by the quail, and that these plants have no negative effects on food assimilation. Oak leaves treatment has the better effects on egg production parameters. Adding vitamin $\mathrm{C}$ to the quail diet improves its physiological hygiene.

\section{REFERENCES}

Abdel-Azim A., El-Kamash EM., El-Bahy N., Hassan Z. S. 2009. Physiological effects of some feed additives under different feeding regimes of Mascovy Ducks . Egypt Poult. Sci. Vil. 29 (1V):1047-1060.

Abdul-Majeed A. F. 2013. Effect of $\mathrm{H}_{2} \mathrm{O}_{2}$-Induced Oxidative Stress, Ginger and Vitamin $\mathrm{C}$ on the Antioxidant Level, Physiological and Productive Performance of Quail and its Progeny. Ph.D Thesis. College of Agriculture University of Mosul, Iraq.

Abdul-Rahman S. Y. and ALObaidy R. N. 2013. Effect of Fenugreek seeds and olive leaves on some physiological characters on laying Hen Breeders. Mesopotamia J. Agri. 41(3):111-121

Abdul-Rahman S.Y., Alrahawi G.A.M. 2012. Effect of vitamin $\mathrm{E}$ and $\mathrm{C}$ on sexual puberty, some biochemical characters and egg quality of quail (Coternix coternix). Vet. J. 26(3):295-301

Abdul-Rahman S.Y. 2008. Effect of oak (Quercus Aegilops) leaves extract on blood glucose \& lipid profile in rabbits. Mesopotamia Agri. J. 36(3):5762.

Abdul-Rahman S.Y., Jankir M.H., Alkatan M.M., 2001. Effect of oak leaves extract on blood glucose and cholesterol in chicken. Raf J.Sci. 12(2):5-9
Abdul-Rahman S.Y., Jankir M.H., Alkatan M.M. 2005. Effect of oak leaves boiled extract on some physiological and biochemical parameters in local male rabbits. Raf. J. Sci. 16(6): 39- 44.

Abdul-Rahman S.Y., Al- Kattan M.M. 2013. Effect of Fenugreek seeds and olive leaves on Antioxidant status, some reproductive and productive parameters in laying hens. Proceeding of the first international scientific conference of college of Agriculture and college of Veterinary medicin. Tikrit. J. Agric. Sci. 13(4):81-90

Akimoto S., Tanihata J., Kawano F., Sato S., Takei Y., Shirayo K., SomeyaY., Nomura S., Tachiyoshiki K. Imazziumi K. 2009. Acute effect of dihydrocapsaicin and capsaicin on the distribution of white blood cells in rats. J. Nutr. Sci. Vitaminol, 55:282-287.

Alishlash H.T. 2012. Effect of Cholesterol \& Boiled Extract of Red Pepper on Numbers of Physiological \& Biochemical \& Histological Criteria of Localmale Rabbits. M.Sc. Thesis. College of Science, Uni. of Mosul- Iraq.

Al-Kassie Galib A.M., Al-Nasrawi Mamdooh A.M., Ajeena Saba J. 2011. The effects of using hot red pepper as a diet supplement on some performance traits in broiler. Pakistan nutrition J. 10 (9): 842845.

Al-Krad H, Abdul-Rahman S.Y., Abdul-Majeed A.F. 2012. Effect of Zingiber, Vitamin C and Hydrogen Peroxide on some physiological and productive parameters in male quails. Res. J. ALFurat. Univ. Basic Sci. series. (26).

Barreto M.S.R., Menten J.F.M., Racanicci A.M.C., Pereira P.W.Z., Rizzo P.V., 2008. Plant extracts used as growth promoters in broilers. brazilian. J. Poult. Sci. 10(2):109-115

Donker R.A., Nieuwland M.G. B. Vander Zijpp A. J. 1990. Heat stress influences on antibody production in chicken lines selected for high and low immune responsiveness. Poult. Sci. 69:599607.

Duncan, D.B. 1955. Multiple and multiple F test Biometrics 11:1-42. 
El-Fiky, A. A. 1998. Addition of ascorbic acid to relive the adverse effects of using underground and saline water on egg quality and some physiological parameters. Egypt., Poultry Scie. 18(1): 81-101.

Erhan M. K., Bölükbaşi S. C. 2011. Effects of feeding diets supplemented with vitamin e and vitamin $\mathrm{c}$ on Performance, egg quality and stereological and structural analysis of the liver of laying hens exposed to heat stress. Italian J. of Animal Sci. 10(5):5-8

Fernandez, de simon B. Cadahia, E. Conde, M.C. Garcia- Valligo. 1996. Low molecular weight phenolic compounds in spanish oak woods .J. Agri. Food. Chem. American Chemical Society. June, 44(6), pp:1507-1511.

Hemid A.E.A., Abdel-Gawad, A.H., El- Wardany I. El-Daly Eman F., Abde-ElAzeem, N. A. 2010. Alleviating effect of some environmental stress factors on production performance in Japanese quail 2. laying performance. World Journal of Agricultural Sciences, 6 (5): 517- 524.

Ibrahim, T.K., Potros, G.Y. 2009.The role of red pepper crush \& watery extract supplementation to the drinking water and ration in alleviating heat stress in broilers. Iraqi. J. Vet. Sci. 23(2):435-443.

Kidd, M. T., Barber, S. J. Zumwalt, C. D. Branton, S. L. Hoehler, D. 2003. A treatise on chicken dam nutrition that impacts on progeny. J. World's Poult. Sci. J. 59(4): 475-494.

Kobata K., Iwasawa T., Iwasaki Y., Morita A., Suzuki Y., Kikuzaki H., Nakatani N., Watanabe T. 2006. Capsaicinol: synthesis by allylic oxidation and its effect on TRPV1-expresing cells and adrenalin secretion in rats. Biosci. Biotechnol. Biochem. 70:1904-1912

Konca Y. F., Kirkpinar S., Mert and Yurt S. 2009. Effects of dietary ascorbic acid supplementation on growth performance, carcass, bone quality and blood parameters in broilers during nutrial summer temperature Asian Journal of Animal and Veterinary Advances, 4 (3) : 139-147.

Lin H., Jiao H. C., Buyse J., Decuypere. 2006. Strategies for preventing heat stress in poultry.World Poult. Sci. J. (62):71- 85.

Lupton A.U., Hoston C.J., Hollway J.E., Warrington J.W., Waldrons B.G., Thompson D.F., Pfeiffer P.V. and Qiek F.A. 1996. Animal performance and flese characteristics of Angora gouts maintained on western and southern Texas rangeland. J. anim. Sci. champagu, ill: American Society of animal science. mar. 74 (3); 545-550.

Mbajiorgu C.A. 2011. Effect of dietary ascorbic acid supplement on egg production, egg quality and hatchability of indigenous Venda chicken hens. Asian J.vet. Advance 6 (8): 823- 830.
NRC, 1994. National Research Council. Nutrient Requirements of poultry, 9th rev. ed. National academy press, Washington, D.C.

Paterson R.T. 1993. Use of trees by livestock. Quercus. In: Natural Resources Institute. Central Avenue. Chatham Maritime, Kent, United Kingdom.

Puthpongsiriporn, U., Scheideler, S. E., Sell, J. L., Beck, M. M. 2001. Effect of vitamin E and C supplementation on performance, in vitro lymphocyte proliferation, and antioxidant status of laying hens during heat stress. Poultry Sci. 80(8): 1190-1200.

SAS. 2008. SAS Users Guide: Statistics, version 9.2 2nd ed., SAS Institute, Inc. Raleigh, North Carolina, USA

Smeets A.J., Lejeune M. P. 2005. Sensory and gastrointestinal satiety effects of capsaicin on food intake. Int. J. Obes., 29: 682-688.

Taha, A.T. 2008. The role of vitamin A, C and nugreek seeds in lowering oxidative stress effect on physiological \& reproductive performance of males broiler breeder. PhD Thesis. College of Agri. and Forestry. Univ. of Mosul-Iraq.

Taha, A.T., Abdul-Rahman S. Y. 2011. Effect of the oxidative stress (Induced by $\mathrm{H}_{2} \mathrm{O}_{2}$ ) and Vitamin $\mathrm{C}$ in some serum traits and Antioxidant status in Broiler Breeder male. 5th Scientific conference of college of Agriculture, 26-27 April, Tikrit University.

Tayeb I. T., Yokhana, J. S., Amedy, V.J.A., 2011. Effect of Ascorbic Acid and Potassium Chloride Supplementation on Performance and Some Physiological Parameters in Broiler Chicks Reared under Summer Condition. International J. Poult. Sci. 10 (3): 247-250

Tolan I., Ragoobirsingh D., Morrison E.Y., 2001.The effect of capsaicin on blood glucose, plasms insulin levels, insulin binding in dog models. Phytother. Res., 15: 391- 394.

Trasel C.K., Schmidt C., Silva C.B., Paim F.C., Rosa A.P., Walkmar P., Alves S.H., Santurio J.M., Lopes, S.T. 2010. Serum biochemical profile and performance of broiler chickens fed diet containing essential oil and pepper. Comp. Clin. Pathol., 1:1010- 1018.

Tuleun, C.D., Adenkola, A.Y., Afele, T. 2011. Effect of dietary ascorbic acid supplementation on the performance of japanese (coturnix coturnix japonica) quails in a tropical environment. J. A. P. S. 10:1268- 1275.

Usman, B. A., Mani A. U., Muyiwa, O. B. 2008. Effect of dietary treatment of Ascorbic Acid on the blood parameters, egg production and quality in quail (coturnix coturnix japonica) Subjected to heat stress. International J. of Poultry Sci., 7 (4): 344-349. 
Whitehead, C.C., Keller, T. 2003. An update on ascorbic acid in poultry. World's Poultry Sci. J. 59:161-184.

Zoipapoutsi, Eva K, Anna T., Nikolas, F. Chrousos G.P., Paraskevi, M. 2005. Evaluation of estrogenic/antiestrogen activity of ellagic acid via the estrogen receptor subtypes ER $\alpha$ and ER $\beta$. J. Agric. Food Chem., 53 (20):7715-7720. 